\title{
Is the high ${ }^{15} \mathrm{~N}$ natural abundance of trees in $\mathrm{N}$-loaded forests caused by an internal ecosystem $N$ isotope redistribution or a change in the ecosystem $N$ isotope mass balance?
}

\author{
Peter Högberg • Christian Johannisson • \\ Mona N. Högberg
}

Received: 14 October 2012/Accepted: 22 May 2013/Published online: 1 June 2013

(C) The Author(s) 2013. This article is published with open access at Springerlink.com

\begin{abstract}
High $\delta^{15} \mathrm{~N}$ of tree foliage in forests subject to high $\mathrm{N}$ supply has been attributed to ${ }^{15} \mathrm{~N}$ enrichment of plant available soil $\mathrm{N}$ pools after losses of $\mathrm{N}$ through processes involving $\mathrm{N}$ isotope fractionation (ammonia volatilization, nitrification followed by leaching and denitrification, and denitrification in itself). However, in a long-term experiment with high annual additions of $\mathrm{NH}_{4} \mathrm{NO}_{3}$, we found no change in the weighted average $\delta^{15} \mathrm{~N}$ of the soil, but attributed the high $\delta^{15} \mathrm{~N}$ of trees to loss of ectomycorrhizal fungi and their function in tree $\mathrm{N}$ uptake, which involves redistribution of $\mathrm{N}$ isotopes in the ecosystem (Högberg et al. New Phytol 189:515-525, 2011), rather than a loss of isotopically light N. Here, we compare the effects of additions of urea and $\mathrm{NH}_{4} \mathrm{NO}_{3}$ on the $\delta^{15} \mathrm{~N}$ of trees and the soil profile, because we have previously found higher $\delta^{15} \mathrm{~N}$ in tree foliage in trees in the urea plots. Doing this, we found no differences between the $\mathrm{NH}_{4} \mathrm{NO}_{3}$ and urea treatments in the concentration of $\mathrm{N}$ in the foliage, or the amounts of $\mathrm{N}$ in the organic morlayer of the soil. However, the foliage of trees receiving the highest $\mathrm{N}$ loads in the urea treatment were more enriched in ${ }^{15} \mathrm{~N}$ than the corresponding
\end{abstract}

Responsible Editor: Frank Hagedorn.

P. Högberg $(\varangle)$ · C. Johannisson · M. N. Högberg Department of Forest Ecology and Management, Swedish University of Agricultural Sciences (SLU), Umeå 901 83, Sweden

e-mail: Peter.Hogberg@slu.se
$\mathrm{NH}_{4} \mathrm{NO}_{3}$ plots, and, importantly, the weighted average $\delta^{15} \mathrm{~N}$ of the soil showed that $\mathrm{N}$ losses had been associated with fractionation against ${ }^{15} \mathrm{~N}$ in the urea plots. Thus, our results in combination with those of Högberg et al. (New Phytol 189:515-525, 2011) show that high $\delta^{15} \mathrm{~N}$ of the vegetation after high $\mathrm{N}$ load may be caused by both an internal redistribution of the $\mathrm{N}$ isotopes (as a result of change of the function of ectomycorrhiza) and by losses of isotopically light $\mathrm{N}$ through processes fractionating against ${ }^{15} \mathrm{~N}$ (in case of urea ammonia volatilization, nitrification followed by leaching and denitrification).

Keywords Ectomycorrhiza $\cdot$ Forest soils $\cdot$ Nitrogen deposition $\cdot \mathrm{N}-15$ natural abundance

\section{Introduction}

Under many natural conditions, the supply of nitrogen is limiting plant production in large areas of temperate and boreal forests (e.g., Tamm 1991). In parts of Europe and N. America, nitrogen deposition is now slowly removing this limitation (Galloway et al. 2008). Consequently, forests become $\mathrm{N}$ saturated as the supply of $\mathrm{N}$ exceeds the combined plant and microbial demand for N (e.g., Aber et al. 1998). When this occurs, leaching losses of nitrate become high, as do losses of nitrous oxide, a potent greenhouse gas.

Processes associated with $\mathrm{N}$ loss, e.g., nitrification and denitrification, discriminate against the heavier $\mathrm{N}$ 
isotope, ${ }^{15} \mathrm{~N}$ (Shearer and Kohl 1986; Högberg 1997). Thus, the $\mathrm{N}$ lost is isotopically light, leaving the remaining ecosystem enriched in ${ }^{15} \mathrm{~N}$. As a consequence the ${ }^{15} \mathrm{~N}$ abundance may be a useful indicator of $\mathrm{N}$ losses from forests (Vitousek et al. 1989; Högberg 1990). Indeed, Högberg and Johannisson (1993) reported a correlation between the fractional loss of added $\mathrm{N}$ and an increase in $\delta^{15} \mathrm{~N}$ over time in tree foliage in a long-term $\mathrm{N}$-loading experiment. Likewise, enrichment in ${ }^{15} \mathrm{~N}$ of tree foliage has been found in field surveys of forests subject to high $\mathrm{N}$ loads in both Europe and N. America (e.g., Högberg et al. 1996; Emmett et al. 1998; Pardo et al. 2007). Högberg (1991) and Högberg and Johannisson (1993) also found that trees in plots to which urea, $\mathrm{CO}\left(\mathrm{NH}_{2}\right)_{2}$, had been applied became more enriched in ${ }^{15} \mathrm{~N}$ than did trees in plots to which $\mathrm{NH}_{4} \mathrm{NO}_{3}$ had been added. They ascribed this greater isotope effect to ammonia volatilization and higher rates of nitrification in the urea plots. The enrichment in ${ }^{15} \mathrm{~N}$ was thought to first occur in labile pools of $\mathrm{N}$ in the soil, and, therefore, soon also in the foliage of trees, while the larger pool of less labile $\mathrm{N}$ in the soil should change its isotopic composition more slowly (Johannisson and Högberg 1994).

In addition to these differences in overall ecosystem $\delta^{15} \mathrm{~N}$ there are also distinct patterns of the $\mathrm{N}$ isotope ratio within ecosystems. In forests dominated by ectomycorrhizal (ECM) tree species, which are typical of strongly N-limited temperate and boreal forests (Smith and Read 2008), there is commonly an increase in $\delta^{15} \mathrm{~N}$ with increasing soil depth (Riga et al. 1971; Nadelhoffer and Fry 1988; Melillo et al. 1989; Gebauer and Schulze 1991; Högberg et al. 1996; Billings and Richter 2006; Sah et al. 2006; Lindahl et al. 2007; Hobbie and Ouimette 2009; Wallander et al. 2009). The classical explanation of how this increase develops is that there is a fractionation against the heavier $\mathrm{N}$ isotope during plant $\mathrm{N}$ uptake, which leaves the remaining soil $\mathrm{N}$ enriched in ${ }^{15} \mathrm{~N}$, while subsequently litter depleted in ${ }^{15} \mathrm{~N}$ becomes deposited on the forest floor (Nadelhoffer and Fry 1988). After the discovery that ECM fungi are highly enriched in ${ }^{15} \mathrm{~N}$ relative to their host plants (e.g., Gebauer and Dietrich 1993; Handley et al. 1996; Högberg et al. 1996), we proposed the additional explanation that ECM fungal material may be a precursor of the biologically more stable $\mathrm{N}$ in the lower horizons (Högberg et al. 1996). The high $\delta^{15} \mathrm{~N}$ of ECM fungi has been attributed to isotopic fractionation during transaminations taking place in the fungi when $\mathrm{N}$ is transported from the soil, through the hyphae and into the plants (Hobbie and Ouimette 2009; Hobbie and Högberg 2012). This leaves the fungal material enriched in ${ }^{15} \mathrm{~N}$, while the $\mathrm{N}$ passed on to the host plant is depleted in ${ }^{15} \mathrm{~N}$ relative to the $\mathrm{N}$ source (Högberg et al. 1999). Importantly, the $\delta^{15} \mathrm{~N}$ of ECM plants is variable dependent on variations in the efficiency of transfer of $\mathrm{N}$ through the fungal symbiont along this pathway (Hobbie and Hobbie 2006).

Moreover, we found that in forests subject to high rates of $\mathrm{N}$ deposition or experimental $\mathrm{N}$ loading the uppermost soil horizon could be isotopically heavier than the lower horizons (Högberg et al. 1996), i.e. a pattern contrary to that found under natural $\mathrm{N}$-limited conditions. We assumed that this reflected $\mathrm{N}$ losses from the plant available $\mathrm{N}$ pools through pathways (nitrification followed by denitrification or leaching of nitrate) leading to isotopic enrichment of the remaining plant available $\mathrm{N}$.

Since the early exploratory phase, many studies have confirmed the observation of a higher $\delta^{15} \mathrm{~N}$ in ECM fungal $\mathrm{N}$ as compared to the $\mathrm{N}$ in their host plants (e.g., Taylor et al. 1997, 2003; Högberg et al. 1999; Hobbie et al. 2000; Henn and Chapella 2001; Hobbie and Hobbie 2006; Kohzu et al. 1999; Trudell et al. 2004). The difference of around $10 \%$ in $\mathrm{N}$-limited forests (Taylor et al. 2003) coincides with the difference between the uppermost and lower soil horizons (e.g., Högberg et al. 1996; Lindahl et al. 2007; Hobbie and Ouimette 2009). Recently, Lindahl et al. (2007) studied the relation between the species composition of the fungal community and the variation in $\delta^{15} \mathrm{~N}$ down the soil profile in a boreal forest. They found that there was no change in $\delta^{15} \mathrm{~N}$ during the initial stage of litter decomposition representing a decrease in C:N ratio from c. 130 to 45 , during which saprotrophic fungi dominated the fungal flora. Further down, ECM fungi became dominant and simultaneously the $\delta^{15} \mathrm{~N}$ of the organic material increased from -4.5 to $+6.0 \%$, indicating uptake of $\mathrm{N}$ by ECM trees. This supports the hypothesis that uptake of $\mathrm{N}$ through ECM fungi drives the development of the ${ }^{15} \mathrm{~N}$ enrichment with increasing soil depth (Högberg et al. 1996). Indeed, in N-loaded forests, in which the biomass of ECM fungi was reduced (Högberg et al. 2007), there was a high $\delta^{15} \mathrm{~N}$ in the foliage and the uppermost soil horizon, but lower $\delta^{15} \mathrm{~N}$ in both 6-15 
years after the $\mathrm{N}$ load was terminated, which was also associated with recovery of the ECM fungi (Högberg et al. 2011).

Thus, according to the above there may be two major reasons why plant $\mathrm{N}$ in $\mathrm{N}$-loaded forests becomes enriched in ${ }^{15} \mathrm{~N}$. These are (1) losses of $\mathrm{N}$ associated with processes fractionating the stable $\mathrm{N}$ isotopes, and (2) changes in the function of ECM fungi, especially their role in redistributing $\mathrm{N}$ isotopes in the ecosystem. The two are likely interrelated. However, while most papers in the past have focussed on (1), a recent study of effects of high additions of $\mathrm{NH}_{4} \mathrm{NO}_{3}$ provided little evidence of $\mathrm{N}$ losses as cause of high foliar $\delta^{15} \mathrm{~N}$, which was primarily attributed to change in the function of ECM symbiosis in redistributing $\mathrm{N}$ isotopes in the ecosystem, i.e. (2)(Högberg et al. 2011). Here, we use the urea treatments in the same long-term field experiment, in which case previous studies have shown a higher $\delta^{15} \mathrm{~N}$ in foliage than in plots to which was $\mathrm{NH}_{4} \mathrm{NO}_{3}$ added, to test the hypothesis that the high $\delta^{15} \mathrm{~N}$ in foliage of trees in the high $\mathrm{N}$ urea plots is the result of a change in the soil $\mathrm{N}$ isotope mass balance rather than a result of a change in the role of ECM symbiosis in the redistribution of $\mathrm{N}$ isotopes in the ecosystem.

\section{Materials and methods}

Experiment E55 at Norrliden is located in a Pinus sylvestris $\mathrm{L}$. forest in northern Sweden $\left(64^{\circ} \mathrm{N}\right)$. The forest was planted in 1953 after a prescribed burning in 1952. It is located on gently sloping glacial till, and the soil type is an Orthic Podzol; detailed descriptions of the site, stand, soil, and the experiment, which was established in 1970, are given by Tamm et al. (1999) and Högberg et al. (2006). We use data from the part of E55 involving additions of $\mathrm{NH}_{4} \mathrm{NO}_{3}$ or as urea. The urea plots are situated immediately to the east and upslope relative to the $\mathrm{NH}_{4} \mathrm{NO}_{3}$ plots. The plots are quadratic, $30 \mathrm{~m}$ by $30 \mathrm{~m}$ each, and there are three replicate plots of each treatment. These are N0, N1, $\mathrm{N} 2$, and N3. N0 is the control, to which no $\mathrm{N}$ has been added experimentally; the $\mathrm{N}$ deposition in this area is around $3 \mathrm{~kg} \mathrm{~N} h a^{-1} \mathrm{yr}^{-1}$. The $\mathrm{N}$ additions to N1-N3 started in 1971 at high levels, but were reduced in two steps (Table 1), leading to average $\mathrm{N}$ addition rates per year of $36 \mathrm{~kg} \mathrm{~N} \mathrm{ha}^{-1}$ in $\mathrm{N} 1,72 \mathrm{~kg} \mathrm{~N} \mathrm{ha}^{-1}$ in N2 and $108 \mathrm{~kg} \mathrm{~N} \mathrm{ha}^{-1}$ in N3 through the period 1971-1990.
Table 1 Nitrogen addition rates $\left(\mathrm{kg} \mathrm{N} \mathrm{ha}^{-1} \mathrm{yr}^{-1}\right)$ in the experiment E55, Norrliden, Sweden, over the time period 1971-1990 (there were no additions in 1991 or before the soil sampling in 1992)

\begin{tabular}{lrrr}
\hline Years & N1 & \multicolumn{1}{c}{ N2 } & N3 \\
\hline $1971-1973$ & 60 & 120 & 180 \\
$1974-1976$ & 40 & 80 & 120 \\
$1977-1990$ & 30 & 60 & 90 \\
Total 1971-1990 & 720 & 1,440 & 2,160 \\
\hline
\end{tabular}

Control plots, N0, received only the background deposition of $\mathrm{N}\left(\sim 3 \mathrm{~kg} \mathrm{~N} \mathrm{ha}^{-1} \mathrm{yr}^{-1}\right)$

The $\delta^{15} \mathrm{~N}$ of fertilizer $\mathrm{N}$ derived from $\mathrm{N} 2$ is usually close to $0 \%$ (Högberg 1997); we have asked the one supplier for samples to analyze, but such material has not been archived. Data on $\mathrm{KCl}$-extractable soil $\mathrm{NO}_{3}$ $\mathrm{N}$ from 1988 reported by Aronsson et al. (1999) showed no differences between the two forms of $\mathrm{N}$ added; comparing urea with $\mathrm{NH}_{4} \mathrm{NO}_{3}$ plots, the amounts of $\mathrm{NO}_{3}-\mathrm{N} \mathrm{kg}^{-1} \mathrm{ha}^{-1}$ in the humus layer were 6.0 versus $1.0,19.5$ versus 14.9 and 33.6 versus 27.5 , in the N1, N2 and N3 plots, respectively.

Every year samples of current needles have been taken from 10 trees per plot (located within the inner $400 \mathrm{~m}^{2}$ of the plot) and pooled into one sample per plot. The leaf samples were dried $\left(70{ }^{\circ} \mathrm{C}, 24 \mathrm{~h}\right)$ and archived. Previously, we have reported analytical data on $\% \mathrm{~N}$ and $\delta^{15} \mathrm{~N}$ of current needles in the urea plots from every fifth year from 1970 through to 1990 (Högberg 1991). Here, we report data on these variables for every year for the same period and the treatment effects on $\mathrm{N}$ content and $\delta^{15} \mathrm{~N}$ of the mor-layer soil as sampled in 1992. Data from the $\mathrm{NH}_{4} \mathrm{NO}_{3}$ plots were reported by Högberg et al. (2011), and are shown here to provide a comparison to the data from the urea plots. Samples of the mor-layer were taken, using a $10 \mathrm{~cm}$ diameter auger from five locations within the central $400 \mathrm{~m}^{2}$ of each plot in 1992 . Note that the $\mathrm{N}$ treatments were all suspended in 1991 , and that the sampling in 1992 was conducted before the $\mathrm{N}$ additions to the treatments $\mathrm{N} 1$ and $\mathrm{N} 2$ that year (N3 was terminated in 1990). The mor-layer was divided into its three characteristic horizons, the S-layer (surface horizon comprising litter mixed with mosses and lichens; this horizon contains no plant roots or active ECM mycelium, see Lindahl et al. 2007), the F-layer (so called fermentation-layer containing identifiable fragments of decomposing litter and an abundance of plant roots and fungal mycelium, especially of ECM fungi), and the H-layer (which also contains abundant roots and 
ECM mycelium, but in which the organic matter is of an amorphous character). The mean ecosystem age, the time since the $\mathrm{C}$ was incorporated through photosynthesis, was estimated at 4-6, 11-15 and 27-47 years, for the S-, F- and H-layer, respectively (Franklin et al. 2003). In this forest, the pine trees retain around five ageclasses of needles. Thus, the organic matter in the $\mathrm{S}$ - and F-layers was composed of organic matter produced during the period of the experiment studied here, while the H-layer contains older material. The $\mathrm{N}$ added has contributed to all horizons. Each sample from each soil horizon was weighed separately after drying $\left(70{ }^{\circ} \mathrm{C}\right.$, $24 \mathrm{~h})$.

Dried and finely ground samples of tree needles and soil were analysed for $\% \mathrm{~N}$ and $\delta^{15} \mathrm{~N}$ on an elemental analyser coupled on-line to an isotope ratio mass spectrometer (an ANCA system coupled to a 20-20 IRMS, Europa Scientific Ltd., Crewe, England). We calculated the weighted average $\delta^{15} \mathrm{~N}$ for each soil horizon, and for the entire mor-layer, using the data on soil mass, $\% \mathrm{~N}$ and $\delta^{15} \mathrm{~N}$. We used ANOVA to test for differences between treatments.

\section{Results}

Needle $\mathrm{N}$ concentration and amounts of $\mathrm{N}$ in the mor-layer

The $\mathrm{N}$ concentration of needles rose rapidly in $\mathrm{N}$-loading treatments above the average level $1.2-1.3 \%$ in the control, N0, treatment (Fig. 1a). The highest percentage of $\mathrm{N}$, around $2.4 \%$ in N3, occurred at an early stage of the experiment, and corresponded with the higher $\mathrm{N}$ addition rates through this stage (Table 1). There were no differences in $\% \mathrm{~N}$ of needles as a result of applying the two different forms of N; only the dose mattered (Fig. 2). The total $\mathrm{N}$ content of the mor-layer roughly doubled after the $\mathrm{N}$ additions irrespective of dose or form of $\mathrm{N}$ applied (Table 2). The increases in $\mathrm{N}$ content of the mor-layers in the urea plots corresponded to a retention of 38, 28 and $16 \%$ of the $\mathrm{N}$ added in $\mathrm{N} 1, \mathrm{~N} 2$ and $\mathrm{N} 3$, respectively.

\section{$\delta^{15} \mathrm{~N}$ of needles}

An initial decline in $\delta^{15} \mathrm{~N}$ in $\mathrm{N} 1-\mathrm{N} 3$ indicated that the added $\mathrm{N}$ was isotopically lighter than endogenous

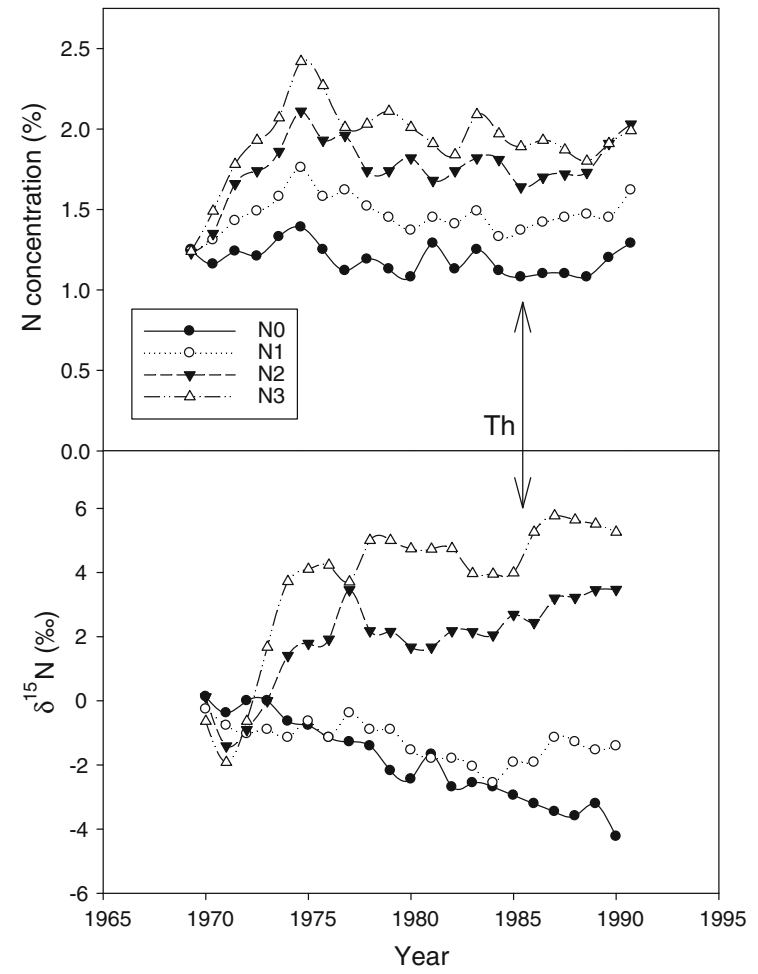

Fig. 1 Concentration of $\mathrm{N}$ (upper panel) and $\delta^{15} \mathrm{~N}$ (lower panel) of needles of $P$. sylvestris trees in the urea plots, 1970-1990, experiment 55, Norrliden, Sweden. Data are plot means. Treatments are described in Table 1 . Th, forest thinning

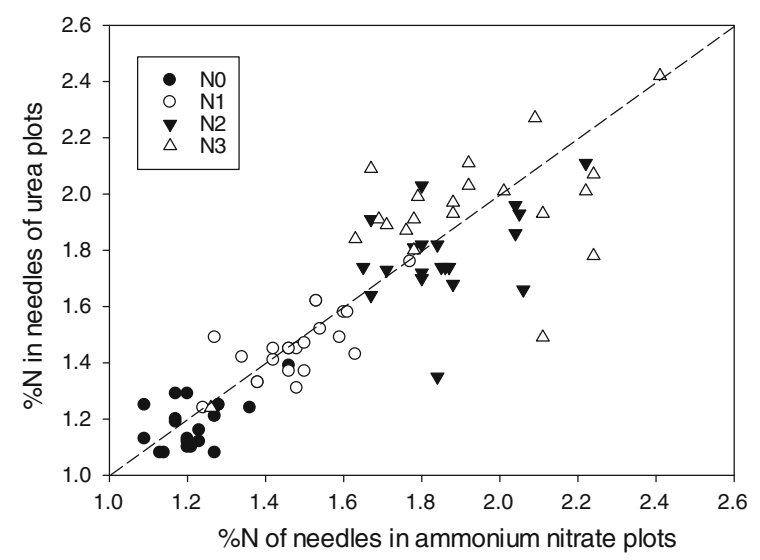

Fig. 2 Concentration of $\mathrm{N}$ in needles in $P$. sylvestris trees in plots treated with $\mathrm{NH}_{4} \mathrm{NO}_{3}$ and urea, 1970-1990, experiment 55 , Norrliden, Sweden. Data are plot means for the same year and treatment. Data for the $\mathrm{NH}_{4} \mathrm{NO}_{3}$ plots are from Högberg et al. (2011). The broken line shows $y=x$. Treatments are described in Table 1

available $\mathrm{N}$ (Fig. 1b). The $\delta^{15} \mathrm{~N}$ of needles in the $\mathrm{N}$-loading treatments started to exceed that in the NO after 3, 4 and 14 years of N-loading in N3, N2 and N1, 
Table 2 Amount of $\mathrm{N}$ (in $\mathrm{kg} \mathrm{ha}^{-1}$ ) in the organic mor-layer in the $\mathrm{NH}_{4} \mathrm{NO}_{3}$ and urea treatments in the experiment E55, Norrliden, Sweden in 1992

\begin{tabular}{lllll}
\hline $\begin{array}{l}\mathrm{N} \text { form } \\
\text { added }\end{array}$ & $\mathrm{N} 0$ & $\mathrm{~N} 1$ & $\mathrm{~N} 2$ & $\mathrm{~N} 3$ \\
\hline $\mathrm{NH}_{4} \mathrm{NO}_{3}$ & $308 \pm 12 \mathrm{a}$ & $565 \pm 31 \mathrm{~b}$ & $656 \pm 47 \mathrm{~b}$ & $700 \pm 83 \mathrm{~b}$ \\
Urea & $332 \pm 43 \mathrm{a}$ & $606 \pm 48 \mathrm{~b}$ & $727 \pm 35 \mathrm{~b}$ & $682 \pm 10 \mathrm{~b}$ \\
\hline
\end{tabular}

There are 3 replicate plots per treatment. The treatments are described in Table 1. Significantly different mean values $(P<0.05$, two-way ANOVA followed by Holm-Sidak's test) are not followed by the same letter. Data are mean $\pm \mathrm{SE}$ Data for the $\mathrm{NH}_{4} \mathrm{NO}_{3}$ treatment from Högberg et al. (2011)

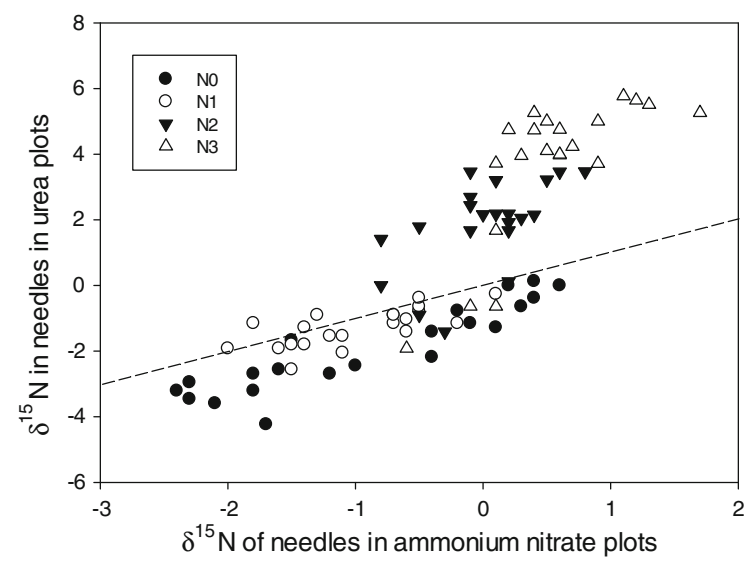

Fig. 3 Natural abundance of ${ }^{15} \mathrm{~N}$ in tree foliage in plots treated with $\mathrm{NH}_{4} \mathrm{NO}_{3}$ and urea, 1970-1990, experiment 55, Norrliden, Sweden. Data are plot means for the same year and treatment. Data for the $\mathrm{NH}_{4} \mathrm{NO}_{3}$ plots are from Högberg et al. (2011). The broken line shows $y=x$. Treatments are described in Table 1

respectively. The changes in $\delta^{15} \mathrm{~N}$ were larger in $\mathrm{N} 2$ and $\mathrm{N} 3$ urea plots than in the corresponding $\mathrm{NH}_{4} \mathrm{NO}_{3}$ treatments (Högberg et al. 2011, Fig. 3), with increases of up to $+6 \%$ in $\mathrm{N} 3$, and a total difference between N3 and N0 of $10 \%$ in 1990. In the N0 plots, the $\delta^{15} \mathrm{~N}$ of needles fell about $4 \%$ in 20 years, i.e. faster than the $2 \%$ in the control plots among the $\mathrm{NH}_{4} \mathrm{NO}_{3}$ treatments (Högberg et al. 2011).

$\delta^{15} \mathrm{~N}$ of organic soil horizons

The data on $\delta^{15} \mathrm{~N}$ of the mor-layers from 1992 showed larger differences among urea treatments than among the $\mathrm{NH}_{4} \mathrm{NO}_{3}$ treatments, corresponding to the greater above-mentioned differences in the needles (Table 3). The weighted average $\delta^{15} \mathrm{~N}$ of the entire mor-layers in the urea plots were $-0.8 \pm 0.4, \quad-0.7 \pm 0.3$, $1.4 \pm 0.1$ and $2.7 \pm 0.1$ for N0, N1, N2 and N3, respectively. Note that while the amounts of $\mathrm{N}$ retained in the mor-layers were similar for the two forms of $\mathrm{N}$ added (Table 2), the $\delta^{15} \mathrm{~N}$ differed substantially, also with regard to the control plots in the two $\mathrm{N}$ treatment blocks; we are unable to explain the difference between control plots, and have chosen to focus on potential differences within the two $\mathrm{N}$ form treatments in our statistical analysis. Note also that the lack of effect in the $\mathrm{N} 1$ treatment indicates that the $\delta^{15} \mathrm{~N}$ of the urea fertilizer must have been close to that of endogenous soil N (Table 3; Fig. 4). In both N0 and $\mathrm{N} 1 \delta^{15} \mathrm{~N}$ increased with increasing soil depth, while the reverse occurred in N2 and N3 (Fig. 4).

\section{Discussion}

There was no difference in $\% \mathrm{~N}$ of needles between the urea and the $\mathrm{NH}_{4} \mathrm{NO}_{3}$ plots (Fig. 2), nor was there any difference in accumulation of $\mathrm{N}$ in the mor-layer that was related to the form of $\mathrm{N}$ applied (Table 2). Hence, we assume in the following that the plots in the urea treatments were as $\mathrm{N}$-limited or $\mathrm{N}$-saturated as the corresponding plots treated with $\mathrm{NH}_{4} \mathrm{NO}_{3}$. Furthermore, data on $\mathrm{KCl}$-extractable $\mathrm{NO}_{3}{ }^{-}$from the soil in $\mathrm{N}$ treated plots in 1988 (Tamm et al. 1999; Aronsson et al. 1999; the data are given in the "Materials and

Table 3 Weighted (by mass $\mathrm{N}$ ) average $\delta^{15} \mathrm{~N}$ for the organic mor-layer in the $\mathrm{NH}_{4} \mathrm{NO}_{3}$ and urea treatments in the experiment E55, Norrliden, Sweden in 1992

\begin{tabular}{lllll}
\hline $\mathrm{N}$ form added & $\mathrm{N} 0$ & $\mathrm{~N} 1$ & $\mathrm{~N} 2$ & $\mathrm{~N} 3$ \\
\hline $\mathrm{NH}_{4} \mathrm{NO}_{3}$ & $1.0 \pm 0.3 \mathrm{a}$ & $-0.3 \pm 0.1 \mathrm{~b}$ & $0.2 \pm 0.1 \mathrm{a}, \mathrm{b}$ & $0.8 \pm 0.1 \mathrm{a}$ \\
Urea & $-0.8 \pm 0.4 \mathrm{a}$ & $-0.7 \pm 0.3 \mathrm{a}$ & $1.4 \pm 0.1 \mathrm{~b}$ & $2.7 \pm 0.1 \mathrm{c}$ \\
\hline
\end{tabular}

There are 3 replicate plots per treatment. The treatments are described in Table 1. Row by row, significantly different mean values $(P<0.05$, one-way ANOVA followed by Holm-Sidak's test $)$ are not followed by the same letter. Data are mean \pm SE Data for the $\mathrm{NH}_{4} \mathrm{NO}_{3}$ treatment from Högberg et al. (2011) 


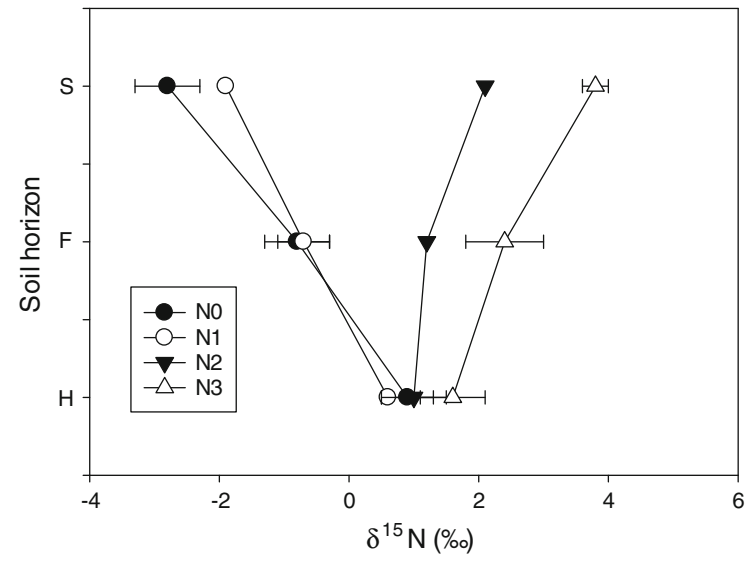

Fig. 4 The $\delta^{15} \mathrm{~N}$ in soil horizons in the urea plots in 1992, experiment 55, Norrliden, Sweden. Data are plot mean \pm SE Treatments are described in Table 1

methods" of this paper) showed no differences between the urea and the $\mathrm{NH}_{4} \mathrm{NO}_{3}$ plots (two-way ANOVA with form of $\mathrm{N}$ and $\mathrm{N}$ dose as factors). This is especially interesting, since in the case of $\mathrm{NH}_{4} \mathrm{NO}_{3}$ half of the $\mathrm{N}$ was added as $\mathrm{NO}_{3}{ }^{-}$, while $\mathrm{NO}_{3}{ }^{-}$in the urea plots must have been produced by nitrifying organisms (Popovic 1985) through a process known to leave the remaining $\mathrm{NH}_{4}{ }^{+}$enriched in ${ }^{15} \mathrm{~N}$ (Högberg 1997).

In the $\mathrm{NH}_{4} \mathrm{NO}_{3}$ treated plots we have previously demonstrated that the major cause of the ${ }^{15} \mathrm{~N}$ enrichment of tree needles in the high $\mathrm{N}$ treatments, in particular, was a loss of the role of ECM fungi in tree $\mathrm{N}$ uptake, and thus in redistributing the $\mathrm{N}$ isotopes in the ecosystem (Högberg et al. 2011). Nitrogen losses occurred in the high $\mathrm{N}$ treatments, but were presumably mainly through leaching (Johannisson et al. 1999), i.e. mass flow, which does not cause isotope fractionation. We previously also observed that the $\delta^{15} \mathrm{~N}$ of the new needles decreased after the termination of the N3 treatment, in which case also DNA sequencing and studies of fatty acid biomarkers also revealed a recovery of ECM fungi. Thus, we (Högberg et al. 2011) observed that the $\delta^{15} \mathrm{~N}$ in the soil profile became similar to that in the control plot and also found no evidence that the $\mathrm{N}$ isotope mass balance had changed; we only saw that the role of ECM symbiosis in redistributing the $\mathrm{N}$ isotopes in the ecosystem was affected by the $\mathrm{N}$ treatments.

In case of the urea plots studied here, the $\mathrm{N}$ mass balance appeared to be roughly the same as for the corresponding $\mathrm{NH}_{4} \mathrm{NO}_{3} \mathrm{~N}$ dose treatments (Table 2), but the isotope effect of $\mathrm{N}$ treatments was clearly larger than in the $\mathrm{NH}_{4} \mathrm{NO}_{3} \mathrm{~N} 2$ and $\mathrm{N} 3$ treatments (Table 3; Fig. 3). A small effect could be attributed to volatilization of $\mathrm{NH}_{3}$ directly from the surfaces of the urea fertilizer pellets (Nömmik 1973); we assume that the elevated partial pressures of $\mathrm{NH}_{3}$ in air around individual urea fertilizer pellets do not overlap, and hence that this process is not dependent on amount of $\mathrm{N}$ applied. Nor does the acidity of the soil matter, since the volatilization occurs before the pellets are dissolved by rain or dew, and thus before the added $\mathrm{N}$ enters the soil. The larger effect on $\delta^{15} \mathrm{~N}$ of foliage seen in the N2 and N3 treatments must, therefore, be explained by the other processes, e.g., enrichment of the remaining pool of $\mathrm{NH}_{4}{ }^{+}$through isotope fractionation during nitrification followed by leaching or denitrification.

Our data from the $\mathrm{NH}_{4} \mathrm{NO}_{3}$ treatment (Högberg et al. 2011) provided clear evidence that the high $\delta^{15} \mathrm{~N}$ of foliage in $\mathrm{N}$-loaded forests may not necessarily involve increased $\mathrm{N}$ losses from the system, but can be a result of internal redistribution of $\mathrm{N}$ isotopes. It may, thus, be important to repeat that the losses of $\mathrm{N}$ from the urea and $\mathrm{NH}_{4} \mathrm{NO}_{3}$ treatments were similar, which suggests that the losses from the latter were not associated with $\mathrm{N}$ isotope fractionation, as expected if leaching of $\mathrm{N}$ added as $\mathrm{NO}_{3}{ }^{-}$is the major agent of loss. However, as shown in the urea treatment, in which case isotopic fractionation during nitrification precedes leaching of $\mathrm{NO}_{3}{ }^{-}$, the $\mathrm{N}$ isotope mass balance cannot be ignored. A good example of this is the very high $\delta^{15} \mathrm{~N}$ of soils at seabird rookeries, where ammonia volatilization and nitrification are important (e.g., Mizutani et al. 1986). With regard to N deposition on forests, which mostly is composed of both $\mathrm{NH}_{4}{ }^{+}$and $\mathrm{NO}_{3}{ }^{-}$, i.e. should be compared with our $\mathrm{NH}_{4} \mathrm{NO}_{3}$ treatment, we propose that internal $\mathrm{N}$ isotope redistribution is the more important driver of early changes in $\delta^{15} \mathrm{~N}$ of tree foliage, after the initial change towards the $\delta^{15} \mathrm{~N}$ of the added $\mathrm{N}$ (Högberg et al. 2011, Fig. 1 here).

Global surveys show a smaller difference in $\delta^{15} \mathrm{~N}$ between trees and soil in tropical as compared to temperate and boreal forests, with plant foliage being particularly low in $\delta^{15} \mathrm{~N}$ relative to soil at the higher latitudes (e.g., Martinelli et al. 1999; Craine et al. 2009). In boreal ECM forests the $\mathrm{N}$ cycle is tightly closed, while in tropical rainforests, where trees with arbuscular mycorrhizal symbiosis are more common, 
the higher $\delta^{15} \mathrm{~N}$ of foliage (Martinelli et al. 1999) is an indicator of a more open $\mathrm{N}$ cycle, especially with regard to the important role of denitrification in $\mathrm{N}$ losses from these ecosystems (e.g., Houlton et al. 2006). We propose that the pivotal role of ECM symbiosis, as shown in the previous study of the $\mathrm{NH}_{4} \mathrm{NO}_{3}$ plots (Högberg et al. 2011) and elsewhere in affecting the distribution of isotopes of $\mathrm{N}$ in ecosystems (e.g., Craine et al. 2009; Hobbie and Ouimette 2009; Hobbie and Högberg 2012), needs to be taken into account if $\delta^{15} \mathrm{~N}$ is used to study $\mathrm{N}$ losses from forest ecosystems.

Acknowledgments This study would not have been possible without the far-sighted efforts of Carl Olof Tamm and his coworkers, who established the Norrliden experiments, and without the financial support from the former Royal College of Forestry, the Faculty of Forest Science (SLU), the Foundation for Plant Nutrition Research, the Swedish Environmental Protection Agency (NV), the Swedish Research Council for Environment, Agricultural Sciences and Spatial Planning (FORMAS) and the Swedish Science Council (VR). We thank Håkan Wallmark for help with the IRMS.

Open Access This article is distributed under the terms of the Creative Commons Attribution License which permits any use, distribution, and reproduction in any medium, provided the original author(s) and the source are credited.

\section{References}

Aber J, McDowell W, Nadelhoffer K, Magill A, Berntson G, Kamakea M, McNulty S, Currie W, Rustad I, Fernandez I (1998) Nitrogen saturation in temperate forest ecosystems. Bioscience 48:921-934

Aronsson A, Flower-Ellis JGK, Popovic B, Tamm CO (1999) Details of soil, stand and responses to fertiliser treatments on the pine (Pinus sylvestris L.) sites Norrliden (1971-1989) and Lisselbo (1969-1988). Report No. 5, Dept. for Production Ecology, SLU, Uppsala, Sweden. ISSN 1401-5625

Billings S, Richter DD (2006) Changes in stable isotopic signatures of nitrogen and carbon during 40 years of forest development. Oecologia 148:325-333

Craine JM, Elmore AJ, Aidar MPM, Bustamante M, Dawson TE, Hobbie EA, Kahmen A, Mack MC, McLauchlan KK, Michelsen A, Nardoto GB, Pardo LH, Penueals J, Reich PB, Schuur EAG, Stock WD, Templer PH, Virginia RA, Welker JM, Weight IJ (2009) Global patterns of foliar nitrogen isotopes and their relationships with climate, mycorrhizal fungi, foliar nutrient concentrations, and nitrogen availability. New Phytol 183:980-992

Emmett BA, Kjonaas OJ, Gundersen P, Koopmans C, Tietema A, Sleep D (1998) Natural abundance of ${ }^{15} \mathrm{~N}$ in forests across a nitrogen deposition gradient. Forest Ecol Manag 101:9-18

Franklin O, Högberg P, Ekblad A, Ågren GI (2003) Pine forest floor carbon accumulation in response to $\mathrm{N}$ and $\mathrm{PK}$ additions: bomb ${ }^{14} \mathrm{C}$ modelling and respiration studies. Ecosystems 6:644-658

Galloway JN, Townsend AR, Erisman JW, Bekunda M, Cai Z, Freney JR, Martinelli LA, Seitzinger SP, Sutton MA (2008) Transformation of the nitrogen cycle: recent trends, questions and potential solutions. Science 320:889-892

Gebauer G, Dietrich P (1993) Nitrogen isotope ratios in different compartments of mixed stands of spruce, larch and beech trees and of understorey vegetation including fungi. Isotopenpraxis 29:35-44

Gebauer G, Schulze E-D (1991) Carbon and nitrogen isotope ratios in different compartments of a healthy and a declining Picea abies forest in the Fichtelgebirge, NE Bavaria. Oecologia 87:198-207

Handley LL, Brendel O, Scrimgeour CM, Schmidt S, Raven JA, Turnbull MH, Stewart GR (1996) The ${ }^{15} \mathrm{~N}$ natural abundance patterns of field-collected fungi from three kinds of ecosystems. Rapid Commun Mass Spectrom 10:974-978

Henn MR, Chapella IH (2001) Ecophysiology of C-13 and N-15 isotopic fractionation in forest fungi and the saprotrophicmycorrhizal divide. Oecologia 128:480-487

Hobbie JE, Hobbie EA (2006) ${ }^{15} \mathrm{~N}$ in symbiotic fungi and plants estimate nitrogen and carbon flux rates in Arctic tundra. Ecology 87:816-822

Hobbie EA, Högberg P (2012) Nitrogen isotopes link mycorrhizal fungi and plants to nitrogen dynamics. New Phytol 196:367-382

Hobbie EA, Ouimette AP (2009) Controls on nitrogen isotope patterns in soil profiles. Biogeochemistry 95:355-371

Hobbie EA, Macko SA, Williams M (2000) Correlations between foliar and nitrogen concentrations may indicate plant-mycorrhizal interactions. Oecologia 122:273-283

Högberg P (1990) Forests losing large quantities of nitrogen have elevated ${ }^{15} \mathrm{~N} /{ }^{14} \mathrm{~N}$ ratios. Oecologia 84:229-231

Högberg P (1991) Development of ${ }^{15} \mathrm{~N}$ enrichment in a nitrogen-fertilized forest soil-plant system. Soil Biol Biochem 23:335-338

Högberg P (1997) ${ }^{15} \mathrm{~N}$ natural abundance in soil-plant systems. New Phytol 137:179-203

Högberg P, Johannisson C (1993) ${ }^{15} \mathrm{~N}$ abundance of forests is correlated with losses of N. Plant Soil 157:147-150

Högberg P, Högbom L, Schinkel H, Högberg M, Johannisson C, Wallmark H (1996) ${ }^{15} \mathrm{~N}$ abundance of surface soils, roots and mycorrhizas in profiles of European forest soils. Oecologia 108:207-214

Högberg P, Högberg MN, Quist ME, Ekblad A, Näsholm T (1999) Nitrogen isotope fractionation during nitrogen uptake by ectomycorrhizal and non-mycorrhizal Pinus sylvestris. New Phytol 142:569-576

Högberg P, Fan H, Quist M, Binkley D, Tamm CO (2006) Tree growth and soil acidification in response to 30 years of experimental N loading. Glob Change Biol 12:489-499

Högberg MN, Högberg P, Myrold DD (2007) Is microbial community composition in boreal forest soils determined by $\mathrm{pH}, \mathrm{C}$-to- $\mathrm{N}$ ratio, the trees, or all three? Oecologia 150:590-601 
Högberg P, Johannisson C, Yarwood S, Callesen I, Näsholm T, Myrold DD, Högberg MN (2011) Recovery of ectomycorrhiza after 'nitrogen saturation' of a conifer forest. New Phytol 189:515-525

Houlton BZ, Sigman DM, Hedin LO (2006) Isotopic evidence of large gaseous nitrogen losses from tropical rainforests. Proc Natl Acad Sci USA 104:8902-8906

Johannisson C, Högberg P (1994) ${ }^{15} \mathrm{~N}$ abundance of forests is correlated with losses of nitrogen. Plant Soil 157:147-150

Johannisson C, Myrold DD, Högberg P (1999) Retention of nitrogen by a N-loaded scotch pine forest. Soil Sci Soc Am J 63:383-389

Kohzu A, Yoshioka T, Ando T, Takahashi M, Koba K, Wada E (1999) Natural ${ }^{13} \mathrm{C}$ and ${ }^{15} \mathrm{~N}$ abundance of field-collected fungi and their ecological implications. New Phytol 144:323-330

Lindahl B, Ihrmark K, Boberg J, Trumbore SE, Högberg P, Stenlid J, Finlay RD (2007) Spatial separation of litter decomposition and mycorrhizal nitrogen uptake in boreal forest. New Phytol 173:611-620

Martinelli LA, Piccolo MC, Townsend AR, Vitousek PM, Cuevas E, McDowell W, Robertson GP, Santos OC, Treseder K (1999) Nitrogen stable isotope composition of leaves and soil: tropical versus temperate forests. Biogeochemistry 46:45-65

Melillo JM, Aber JD, Linkins AE, Ricca A, Fry B, Nadelhoffer KJ (1989) Carbon and nitrogen dynamics along the decay continuum - plant litter to soil organic matter. Plant Soil 115:189-198

Mizutani H, Hasegawa H, Wada E (1986) High nitrogen isotope ratio for seabird rookeries. Biogeochemistry 2:221-247

Nadelhoffer KJ, Fry B (1988) Controls on natural nitrogen-15 and carbon-13 abundances in forest soil organic matter. Soil Sci Soc Am J 52:1633-1640

Nömmik H (1973) Effect of pellet size on ammonia loss from urea applied to a forest soil. Plant Soil 39:309-318

Pardo LH, Hemond HF, Montoya JP, Pett-Ridge J (2007) Natural abundance ${ }^{15} \mathrm{~N}$ in soil and litter across a nitrate-output gradient in New Hampshire. Forest Ecol Manag 251:217-230
Popovic B (1985) The effect of nitrogenous fertilizers on nitrification of forest soils. Fertil Res 6:139-147

Riga A, van Praag HJ, Brigode N (1971) Rapports isotopique naturel de l'azote dans quelques sols forestiers et agricoles de Belgique soumis a divers traitments culturaux. Geoderma 6:213-222

Sah SP, Rita H, Ilvesniemi H (2006) ${ }^{15} \mathrm{~N}$ natural abundance of foliage and soil across boreal forests of Finland. Biogeochemistry 80:277-288

Shearer GB, Kohl DH (1986) $\mathrm{N}_{2}$-fixation in field settings: estimations based on ${ }^{15} \mathrm{~N}$ natural abundance. Austr J Plant Physiol 13:699-756

Smith SE, Read DJ (2008) Mycorrhizal symbiosis, 3rd edn. Ademic Press, London

Tamm CO (1991) Nitrogen in terrestrial ecosystems. Ecol Stud $81: 1-115$

Tamm CO, Aronsson A, Popovic B, Flower-Ellis JGK (1999) Optimum nutrition and nitrogen saturation in Scots pine stands. Stud For Suecica 206:1-126

Taylor AFS, Högbom L, Högberg M, Lyon TJE, Näsholm T, Högberg P (1997) Natural ${ }^{15} \mathrm{~N}$ abundance in fruit bodies of ectomycorrhizal fungi from boreal forests. New Phytol 136:713-720

Taylor AFS, Fransson PM, Högberg P, Högberg MN, Plamboeck AH (2003) Species level patterns in C-13 and N-15 abundance of ectomycorrhizal and saprotrophic fungal sporocarps. New Phytol 159:757-774

Trudell SA, Rygiewicz PT, Edmonds RI (2004) Patterns of nitrogen and carbon stable isotope ratios in macrofungi, plants and soils in two old-growth conifer forests. New Phytol 164:317-335

Vitousek PM, Shearer GB, Kohl DH (1989) Foliar ${ }^{15} \mathrm{~N}$ natural abundance in Hawaiian rainforest: patterns and possible mechanisms. Oecologia 78:383-388

Wallander H, Mörth C-M, Giesler R (2009) Increasing abundance of soil fungi is a driver for ${ }^{15} \mathrm{~N}$ enrichment in soil profiles along a chronosequence undergoing isostatic rebound in northern Sweden. Oecologia 160:87-96 